\title{
Characterisation of water quality in effluents of land-based abalone farms in the Western Cape, South Africa
}

\author{
T. A. Probyn ${ }^{1, *}$, M. Pretorius ${ }^{2}$, K. Seanego ${ }^{1}$, A. Bernatzeder ${ }^{2}$ \\ ${ }^{1}$ Aquaculture Research and ${ }^{2}$ Sustainable Aquaculture Management, Department of Agriculture, Forestry and Fisheries, \\ Private Bag X2, Vlaeberg 8018, Cape Town, South Africa
}

\begin{abstract}
Effluent water quality was measured at 9 abalone (Haliotis midae) farms in 2 regional nodes (west and south) along the South African coastline. For most farms, effluent total suspended solids (TSS) exceeded the background reference level $\left(80^{\text {th }}\right.$ percentile), and 3 did not comply with the $5 \mathrm{mg} \mathrm{l}^{-1}$ standard. Total ammonia nitrogen $\left(\mathrm{NH}_{4}{ }^{+}\right)$concentrations were mostly greater than reference levels but well below the $43 \mu \mathrm{mol} \mathrm{N} \mathrm{^{-1 }}$ standard. Inflow-corrected concentrations of nitrate, nitrite and phosphate were low compared to $\mathrm{NH}_{4}{ }^{+}$and would not pose a significant eutrophication risk. Similarly, the biochemical oxygen demand measured at 3 of the farms was low (median $1.31 \mathrm{mg} \mathrm{l}^{-1}$ ). Abalone production-specific annual loads of TSS (334 kg per metric tonne $[\mathrm{mt}])$, total $\mathrm{N}\left(20.3-38.1 \mathrm{~kg} \mathrm{~N} \mathrm{mt}^{-1}\right)$ and total $\mathrm{P}\left(3.2-7.5 \mathrm{~kg} \mathrm{P} \mathrm{mt}^{-1}\right)$ agree with what has been found for different land-based aquaculture operations. These figures translate to N-based human population equivalents of 5.4-10.6 persons $\mathrm{mt}^{-1}$ for both regions. At the broader ecosystem level, the annual TSS loads calculated from 2013 production data of $43 \mathrm{mt} \mathrm{yr}^{-1}$ (west) and $369 \mathrm{mt} \mathrm{yr}^{-1}$ (south) are, respectively, 0.35 and $2.8 \%$ of that estimated for kelp erosion. Similarly, the dissolved inorganic $\mathrm{N}$ loads of $1.9 \mathrm{mt} \mathrm{N} \mathrm{yr}^{-1}$ (west) and $9.4 \mathrm{mt} \mathrm{yr}^{-1}$ (south) are trivial by comparison with nitrate advected during upwelling. Local abalone farms have a relatively high specific $\mathrm{C}$ footprint - conservatively $\sim 44 \mathrm{~kg} \mathrm{CO}_{2} \mathrm{~kg}^{-1}$ production. Our findings support a relatively low potential impact of farm effluents in this coastal upwelling environment.
\end{abstract}

KEY WORDS: Abalone farm $\cdot$ Effluents $\cdot$ Suspended solids $\cdot$ Nutrients $\cdot$ Haliotis

\section{INTRODUCTION}

Aquaculture has often received media criticism for practices that are perceived as unsustainable environmentally, over and above additional concerns related to food safety, animal welfare and social issues. Much of this criticism has been directed at operations that require feed inputs, such as finfish and shrimp farming. Molluscan shellfish, or more correctly bivalve, culture by way of contrast is often regarded as posing low environmental risk and, in fact, can provide certain ecosystem services, particularly in eutrophic waters (Hargreaves 2011). This favourable perception of bivalves is based primarily on the fact

\footnotetext{
${ }^{*}$ Corresponding author: trevorp@daff.gov.za
}

that they feed on naturally occurring seston which develops in response to nutrient inputs to coastal ecosystems (Burkholder \& Shumway 2011). By virtue of their filter feeding pursuits, bivalves can serve to improve water quality in coastal embayments subject to excessive anthropogenic nutrient loads and concomitant development of phytoplankton blooms.

Land-based abalone Haliotis spp. farming differs from bivalve culture in that feed inputs are required, generally as seaweed or formulated diets. South Africa is currently a significant global producer of farmed abalone, behind only China and Korea (Troell et al. 2006, Cook 2014). The local industry is founded on land-based raceway systems, although

() The authors 2017. Open Access under Creative Commons by Attribution Licence. Use, distribution and reproduction are unrestricted. Authors and original publication must be credited. 
ranching and sea-based cages are currently being explored (DAFF 2014). Initially, the South African abalone farming industry was based largely on fresh seaweed (mainly kelp) feed, but recently artificial feed has assumed prominence. This shift in feeding strategy has implications for dissolved $\mathrm{N}$ release from raceways given the higher protein content of artificial feed (Troell et al. 2006, Naylor et al. 2011). Although much research has been undertaken on various aspects of abalone husbandry from broodstock conditioning to post-harvest handling, effluent quality and potential environmental impacts have not been studied in detail. Findings from the few studies that have been undertaken indicate elevated levels of suspended solids and nutrients, particularly ammonium, in effluents (Samsukal 2004, Yearsley 2007, P. J. Britz \& B. P. Godfrey unpubl. specialist study). The requirement for high water quality by abalone and the release of effluents within the same water body as intake establishes the potential for site-specific environmental impact. Nevertheless, abalone farm effluents are regarded as relatively innocuous (ASC 2012), containing highly diluted levels of wastes and uneaten feed.

There are many examples of standards/guidelines that have been established for the protection of natural ecosystems that could be applied to pipeline discharges. Nationally, the former Department of Water Affairs and Forestry (DWAF 1995) provided guidelines for the protection of the natural marine environment, both as numerical values and as narrative statements. Australia and New Zealand have developed a comprehensive set of guideline trigger values for a wide range of physical and chemical stressors, as well toxicants in different categories of aquatic ecosystems (ANZECC \& ARMCANZ 2000). The preferred approach in setting these guidelines is to use local biological and/or ecological effects data, but where these are not available, local reference data may be used. This approach adopts the $80^{\text {th }}$ percentile of a reference condition as a conservative guideline for stressors that may cause problems at high concentrations. Reference system data are obtained from the same or a similar ecological system, in an undisturbed condition. These guidelines are applied as low-risk trigger levels that will initiate further site-specific investigation should they be exceeded.

There are considerably fewer examples of water quality guidelines specific to land-based aquaculture facilities. Of particular relevance to the present study are the abalone standards adopted by the Aquaculture Stewardship Council (ASC 2012) as the basis for a certification programme. The standards provide principles, criteria, indicators and standards for addressing a number of potentially negative social and environmental aspects of abalone aquaculture. With regard to discharges from land-based abalone farms, the most important indicators of water quality are total suspended solids (TSS) and total ammonium N $\left(\mathrm{NH}_{4}{ }^{+}\right)$. Limits applied to effluents at the point of discharge are an annual median concentration of $<5 \mathrm{mg}$ $\mathrm{l}^{-1}$ TSS compared to inflow and $<600 \mu \mathrm{g} \mathrm{l}^{-1} \mathrm{NH}_{4}{ }^{+}$ $\left(43 \mu \mathrm{mol} \mathrm{N}{ }^{-1}\right)$ in effluents. The $\mathrm{NH}_{4}{ }^{+}$limit is apparently uncorrected for influent levels, in contrast with TSS. If measured concentrations in effluents comply with these standards, then effluent sampling is all that is required. Otherwise, receiving water concentrations beyond a zone of initial dilution (mixing zone) need to be considered.

This study builds on preliminary studies of effluent quality for local land-based farms (Samsukal 2004, Yearsley 2007) in an attempt to identify potential environmental stressors of concern both at the local scale and the broader coastal ecosystem level. The present results for end-of-pipeline discharges are compared both with reference percentile data, as in the Australian/New Zealand approach (ANZECC \& ARMCANZ 2000), and with the abalone dialogue standards (ASC 2012).

\section{MATERIALS AND METHODS}

\section{Sampling}

Sampling was limited to the Western Cape where the majority of established abalone (Haliotis midae) farms are located (Fig. 1). Company names have been excluded from this study to maintain anonymity of the different facilities. All farms employed flowthrough raceway systems with the exception of Farm I, which operated on recirculation with a varying proportion of make-up water. This farm has subsequently ceased operations. Farms have been grouped into 2 nodes according to region: the 6 farms from Hermanus/Gansbaai (Farms A-F), are referred to as 'south coast' for convenience; and the 3 farms from the vicinity of St Helena Bay are referred to as 'west coast' (Farms G-I). Each farm was sampled on 5 occasions ( 6 for Farm A) and at various times of the year between 2009 and 2015, such that all seasons were covered for each regional node.

Water samples were collected at each farm from effluent streams, inflow to the grow-out tanks and, in most cases, intake to the farm itself. Multiple effluent streams (Farms A and C) and inflows (Farm H) were 


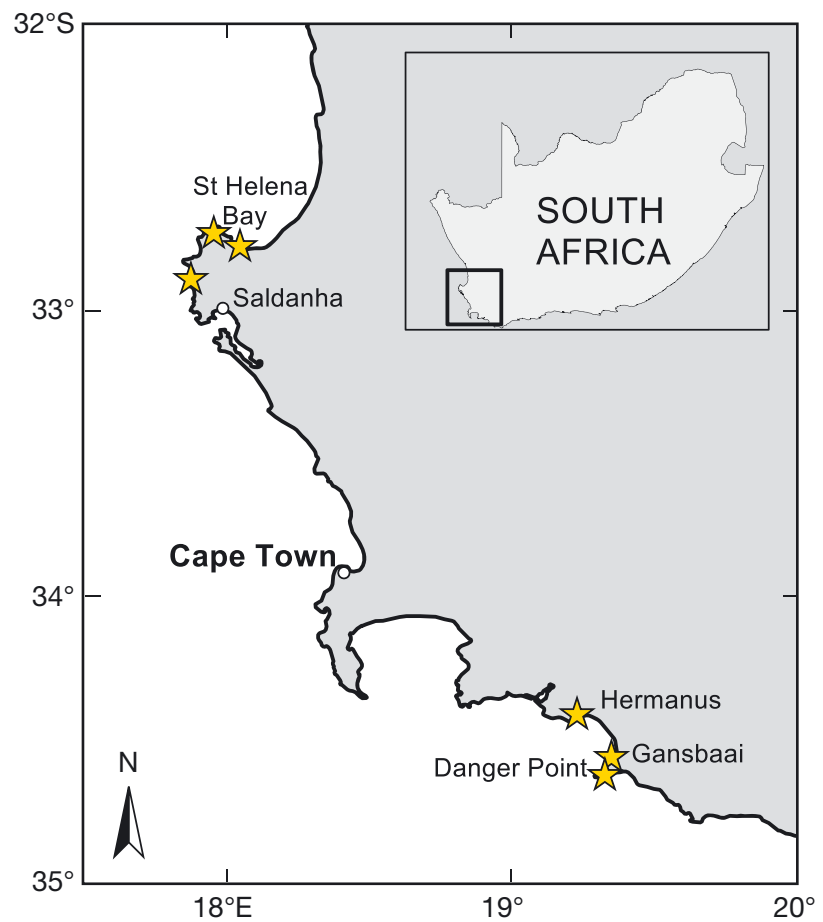

Fig. 1. Location of 'west coast' abalone farms near St Helena Bay and 'south coast' farms in the Hermanus/Gansbaai area, South Africa. Stars indicate locations of individual farms or clusters of farms

sampled individually. Tank inflow and farm intake samples were taken separately, as a number of farms employed some form of particle reduction in intake water prior to release to the tanks. This included drum filtration (Farms A, D, E and F) and settlement, either in ponds (Farms A, F, G and H) or, to a limited degree, in header tanks. The effects of such treatment was, as expected, most obvious for the particulate fractions and less so for dissolved components. Farm intake samples, i.e. prior to any filtration or settlement, are regarded as approximating 'ambient' conditions and are employed as an indicator of background concentrations. For those farms with no filtration treatment and minimal settling in header tanks (Farms B, C and I), intake and inflow samples may be treated as approximately equal. Effluent signals for Farm $\mathrm{F}$ included the effect of seaweed culture integrated into the reticulation system.

Samples were collected twice during the day, during working hours and after hours, to account for routine farm activities. In calculating activity-based concentrations, measured concentrations were initially weighted for an 8:16 h working:non-working day to provide an average daily value for a working day. Non-working days corresponded to $24 \mathrm{~h}$ of the measured after-hours signal. These were then weighted annually using $250 \mathrm{~d}$ as the typical number of working days in a year and $115 \mathrm{~d}$ as non-working.

Effluent flow rates were either provided by the respective farm management staff for the day of sampling or calculated directly from measurements of surface velocity and channel dimensions (Farms A, G and I). Measured surface flow velocities were corrected for flow variation with depth by a factor of 0.85 (Meals \& Dressing 2008). Multiple effluent streams were combined as a single outflow for each farm, and water quality parameters ultimately presented as a single concentration weighted by flow rate for each channel. Similarly, the 2 different inflows for Farm H were combined to give a single concentration weighted according to respective pump capacity.

\section{Abalone biomass and production}

Standing stock data on the day of sampling, as whole wet weight, as provided by the farms, were correlated with volume flow rates to provide a specific discharge rate. Standing stock data included only grow-out sections of a farm; hatchery data (animals $<10-15 \mathrm{~mm}$ ) were not included. Standing stock data were used to provide estimates of average annual production assuming a production:biomass (P:B) ratio of 1.2 (M. Naylor, HIK Abalone Farm, pers. comm.) for the south coast farms that are fed predominantly an artificial diet, and 0.83 for the mainly kelpfed west coast farms (D. Whyte, West Coast Abalone, pers. comm.). This is equivalent to average specific growth rates $(\ln [1.83] / 365 \times 100$ and $\ln [2.2] / 365 \times$ 100 ) of 0.17 and $0.22 \% \mathrm{~d}^{-1}$, for west and south coast farms, respectively, which is in agreement with that measured for market-sized abalone on formulated feed and kelp diets (Francis et al. 2008).

\section{Suspended solids}

TSS were measured gravimetrically on $47 \mathrm{~mm}$ Whatman GF/F filters (nominal pore size $0.7 \mu \mathrm{m}$ ) that had been thoroughly rinsed with Milli-Q under vacuum to remove friable material and combusted at $450^{\circ} \mathrm{C}$ overnight in a muffle furnace. Following combustion, filters were cooled in a vacuum desiccator over silica gel and weighed to the nearest $0.1 \mathrm{mg}$ using a Radwag semi-micro, analytical balance. Generally, 1 to 41 of sample were filtered, depending on particle load, rinsed thoroughly with Milli-Q water (approximately $200 \mathrm{ml}$ ), and stored at $-20^{\circ} \mathrm{C}$ for later processing. Some samples taken initially $(n=36)$ 
were screened through a $63 \mu \mathrm{m}$ plankton mesh prior to filtration and subsequent weighing to provide an estimate of the proportion of silt-sized particles.

Both thorough mixing and rinsing (400-450 ml) to remove sea salt held in the filter matrix are crucial to accurate TSS measurements in seawater (Neukermans et al. 2012). Because a rinse volume of $200 \mathrm{ml}$ as used here is insufficient to remove all salt from the filter matrix (Neukermans et al. 2012), we applied corrections for salt and water of hydration (Stavn et al. 2009) where necessary as determined by measurements on filter blanks conducted in our laboratory. Organic material may be lost by rupture of intact cells during the Milli-Q rinse. However, such material losses are considered to be of less significance on glass fibre filters than other filter matrices (van der Linde 1998, cited by Neukermans et al. 2012). In addition, the organic particulate matter in abalone effluents consists mainly of faeces and uneaten feed (predominantly a formulated diet) which is likely to have a low proportion of intact cells. The presence of living cells in inflow water is partially compensated by subtraction from effluent TSS. The salt correction proved to be insignificant $(0.046 \mathrm{mg}$ filter $^{-1}$ ) given the heavy particle loads on the filters. As the intention was to load the filter with as much particulate matter as practically possible to improve the signal to blank ratio, some filtrations took over $1 \mathrm{~h}$ to complete. Given time constraints in the field and long filtration times, TSS measurements were not routinely replicated. However, agreement between replicates can be expected to be better than $5 \%$ (replicates CV $=2.54 \%, \mathrm{n}=15$ ). Heavy loading on filters would obviously result in clogging and hence reduction in effective pore size for such samples, although this effect is considered minor given the mass of material on the filters.

On return to the laboratory, filters were dried at $60^{\circ} \mathrm{C}$, cooled under vacuum, and re-weighed. Inorganic matter was determined on a subset of samples after ignition at $450^{\circ} \mathrm{C}$ overnight. Ashed values were corrected for water of hydration $\left(0.656 \mathrm{mg} \mathrm{filter}^{-1}\right)$ following Stavn et al. (2009). All TSS concentrations are presented as mg dry weight $\mathrm{l}^{-1}$.

\section{Particulate $\mathbf{N}$ and $\mathbf{P}$}

Particulate $\mathrm{N}$ was measured on a separate subset of samples according to the persulfate oxidation method based on Raimbault \& Slawyk (1991). Following digestion in an oven at $120^{\circ} \mathrm{C}$ for $2.5 \mathrm{~h}$, an aliquot of the assay mixture was diluted 5 times with Milli-Q water and adjusted to $\mathrm{pH} 8$ with Tris-HCl buffer to a final concentration of $0.01 \mathrm{M}$. Nitrate reduction was carried out on a cadmium column following the manual method of Nydahl (1976). Analyses of particulate P followed Suzumura (2008), with persulfate oxidation in an oven at $120^{\circ} \mathrm{C}$ for $2 \mathrm{~h}$ followed by manual $\mathrm{PO}_{4}{ }^{3-}$ analyses (Grasshoff et al. 1983). The present modification of employing oven digestion at $120^{\circ} \mathrm{C}$ for longer time periods than recommended in the original methods gave slightly better recoveries for $\mathrm{N}$ $(p=0.017)$, and similar recoveries for $P$, compared to autoclave digestion (Mann-Whitney rank sum tests).

\section{Biochemical oxygen demand}

Biochemical oxygen demand (5 d) measurements were conducted at 3 farms: 2 from the west coast (including Farm I, which operated on recirculation) and 1 from the south coast. Samples were taken twice a day from each farm, during and after working hours, and analysed in triplicate. Each sample comprised 6 replicate $120 \mathrm{ml}$ Winkler bottles of which 3 were immediately fixed for analysis of dissolved oxygen concentration according the Winkler method of Carpenter (1965). The remaining 3 were incubated at $20^{\circ} \mathrm{C}$ for $5 \mathrm{~d}$ in the dark prior to final oxygen determinations.

Samples were not treated with a bacterial seed, as the natural populations of micro-organisms present were regarded as adequate to facilitate the decomposition process. Dilution of samples to maintain oxygen depletion within bounds was also not deemed necessary, as 5 d biochemical oxygen demand $\left(\mathrm{BOD}_{5}\right)$ values $<7 \mathrm{mg} \mathrm{l}^{-1}$ were expected (limit given by Delzer \& McKenzie 2003). The median $\mathrm{BOD}_{5}$ was 1.51 to $3.31 \mathrm{mg} \mathrm{l}^{-1}$ for all 3 farms, with values very slightly in excess of $7 \mathrm{mg} \mathrm{l}^{-1}$ occurring only occasionally. Another criterion for acceptable BOD values is that the final oxygen concentration should be $>1 \mathrm{mg}$ $\mathrm{l}^{-1}$ (Delzer \& McKenzie, 2003). Median final oxygen concentrations were 4.48 to $6.65 \mathrm{mg} \mathrm{l}^{-1}$ for the 3 farms with concentrations $<1 \mathrm{mg} \mathrm{l}^{-1}$ occurring on only 1 occasion.

\section{Dissolved nutrients}

Inorganic nutrients were determined on Whatman GF/F filtered samples generally within $2 \mathrm{~h}$ of collection. Total ammonium nitrogen $\left(\mathrm{NH}_{4}{ }^{+}\right)$, soluble reactive phosphate $\left(\mathrm{PO}_{4}{ }^{3-}\right)$ and nitrite $\left(\mathrm{NO}_{2}{ }^{-}\right)$were measured in triplicate according to the manual methods described by Grasshoff et al. (1983), and nitrate 
$\left(\mathrm{NO}_{3}{ }^{-}\right)$following the cadmium reduction method of Nydahl (1976). All methods were scaled to $5 \mathrm{ml} \mathrm{sam-}$ ple volume. The mean SDs, in $\mu \mathrm{mol}^{-1}$, for replicates in this study were 0.10 for $\mathrm{NH}_{4}{ }^{+}, 0.18$ for $\mathrm{NO}_{3}{ }^{-}, 0.03$ for $\mathrm{NO}_{2}{ }^{-}$and 0.02 for $\mathrm{PO}_{4}{ }^{3-}$.

\section{Nutrient budget}

Although not the primary aim of the present study, partial $\mathrm{N}$ and $\mathrm{P}$ budgets were formulated for those farms where feed and harvest data were available. Data from 2015 were used as example case studies. This exercise provides an indicator of the magnitude of losses not accounted for in the sampling programme. Annual farm inputs, as artificial feed and seaweed provisions, and outputs, as harvested and discharged particulate and dissolved inorganic fractions, were formulated from farm data on monthly feed usage and standing stock. Inputs were converted to a production basis using $\mathrm{P}: \mathrm{B}$ ratios of 0.83 and 1.2 for the west and south coast farms, respectively. Farm output data were calculated for harvested soft tissue/shell, and dissolved/particulate components in the effluent. Effluent data, corrected for inflow, were based on the generic, industry-wide relationships formulated in this study.

\section{Statistics}

Normality of data was established with the ShapiroWilk test. Differences between variables with a normal distribution were tested using a $t$-test. Comparisons between non-normal distributions used the Mann-Whitney rank sum test for independent samples and the Wilcoxon signed-rank test for matched samples. The significance level was set at $\mathrm{p}<0.05$ for all comparisons. All regression analyses and statistical tests, with the exception of analysis of covariance (ANCOVA), were performed in SigmaPlot 12.0. Comparison of regressions by ANCOVA followed the procedures given by Zar (1974). The median absolute deviation was calculated as half the interquartile range.

\section{RESULTS}

\section{Flow rates}

We found a significant relationship between standing stock and volume flow rates at the farm level (Fig. 2). The specific discharge rate for all farms col-

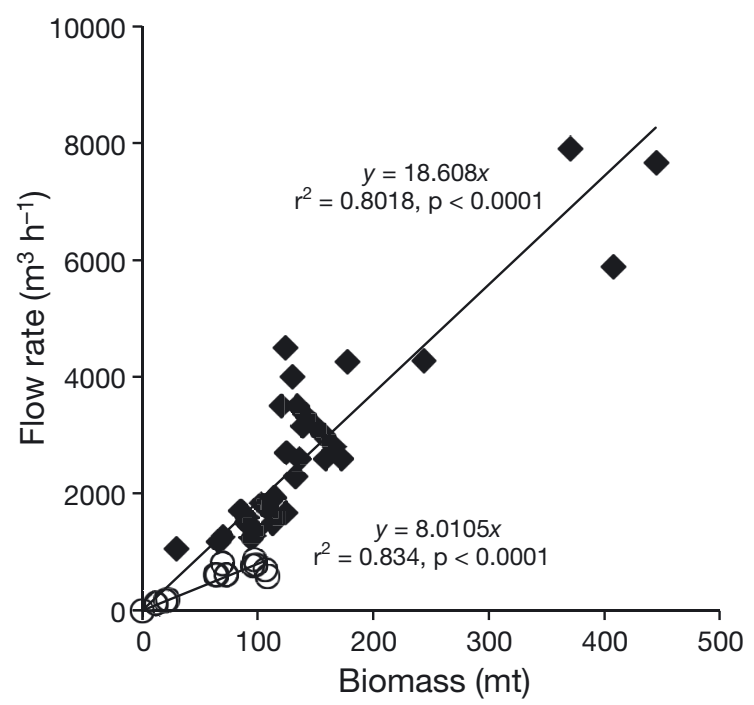

Fig. 2. Relationship between flow rate and standing stock for south coast (filled diamonds) and west coast (circles) abalone (Haliotis midae) farms. Regressions were formulated in SigmaPlot 12.0 and compared using ANCOVA

lectively was $17.9 \mathrm{~m}^{3} \mathrm{~h}^{-1}$ metric tonne $(\mathrm{mt})^{-1}$ (or $1 \mathrm{~h}^{-1}$ $\mathrm{kg}^{-1}$ ). The west coast farms tended towards slower rates, i.e. $8.0 \mathrm{~m}^{3} \mathrm{~h}^{-1} \mathrm{mt}^{-1}$ (inclusive of Farm I that functioned on variable recirculation) as opposed to south coast farms only (18.6 $\mathrm{m}^{3} \mathrm{~h}^{-1} \mathrm{mt}^{-1}$; Fig. 2). Excluding the recirculation farm had a negligible effect on these rates. The different rates are statistically significant (ANCOVA, p < 0.001), suggesting considerably lower pumping costs for west coast farms.

\section{Particulate matter composition}

Particles $<63 \mu \mathrm{m}$ comprised 87 and $79 \%$ of the total dry mass, respectively, for the inflow and effluent streams (Table 1). The difference between inflow and effluent values was not statistically significant (median $=83 \%$ ). Concentrations were significantly larger in effluent streams for organic matter and particulate $\mathrm{N}$ and $\mathrm{P}$. This was most noticeable for $\mathrm{N}$ where effluent streams were almost double that of the inflow for both regions. A significant difference between regions was found only for particulate $N$, where values for south coast farms exceeded those of the west coast.

\section{Water quality}

Median TSS concentrations in farm effluent waters measured during working hours $\left(10.07 \mathrm{mg} \mathrm{l}^{-1}\right)$ exceeded those measured after hours $\left(0.56 \mathrm{mg} \mathrm{l}^{-1}\right)$ for 
Table 1. Composition of particulate matter in seawater inflow and effluents for abalone (Haliotis midae) farms either combined, where no significant difference between regions (S: south, W: west) was evident (Mann-Whitney rank sum test, $\mathrm{p}>0.05)$, or separated into the 2 regions $(\mathrm{p}<0.05)$. Data were not normally distributed and are presented as a median. The median absolute deviation is given in parentheses. ${ }^{*}$ Denotes a significant difference between inflow and effluent values

\begin{tabular}{|c|c|c|c|c|c|c|}
\hline \multirow[t]{2}{*}{ Variable } & \multirow[t]{2}{*}{ Region } & \multicolumn{2}{|c|}{$\longrightarrow$ Inflow $\longrightarrow$} & \multicolumn{2}{|c|}{$\longrightarrow$ Effluent } & \multirow[t]{2}{*}{$\mathrm{p}$} \\
\hline & & $\mathrm{n}$ & Median (SD) & $\mathrm{n}$ & Median (SD) & \\
\hline $\begin{array}{l}<63 \mu \mathrm{m} \text { fraction } \\
(\% \text { total })\end{array}$ & $\mathrm{S} \& \mathrm{~W}$ & 19 & $87.14(12.83)$ & 19 & $78.77(20.30)$ & 0.260 \\
\hline $\begin{array}{l}\text { Organic matter } \\
\text { (\% dry weight) }\end{array}$ & $\mathrm{S} \& \mathrm{~W}$ & 43 & $57.52(14.35)$ & 50 & $63.82(14.12)$ & $0.017^{*}$ \\
\hline $\begin{array}{l}\text { Particulate } \mathrm{P} \\
\text { (\% dry weight) }\end{array}$ & $\mathrm{S} \& \mathrm{~W}$ & 45 & $0.24(0.07)$ & 49 & $0.33(0.13)$ & $0.017^{*}$ \\
\hline Particulate N & $\mathrm{S}$ & 27 & $1.08(0.44)$ & 31 & $2.02(0.63)$ & $<0.001^{*}$ \\
\hline (\% dry weight) & W & 53 & $0.76(0.24)$ & 23 & $1.43(0.41)$ & $<0.001^{*}$ \\
\hline
\end{tabular}

able variability with respective median absolute deviations of $4.10 \mathrm{mg} \mathrm{l}^{-1}$ and $7.03 \mathrm{mg} \mathrm{l}^{-1}$. Differences between net effluent concentrations were not significantly different ( $t$-test, $\mathrm{p}=0.600)$, yielding a combined value of $4.18 \mathrm{mg}$ $1^{-1}$ for all data.

The dissolved components of abalone farm discharges show very little difference between working and non-working hours signals for both raw effluent and inflow-corrected effluent. For example, mean inflow-corrected $\mathrm{NH}_{4}^{+}$concentrations for working (3.44 $\mathrm{mmol} \mathrm{N} \mathrm{l}^{-1}$ ) and non-working (3.39 $\mu \mathrm{mol} \mathrm{N}^{-1}$ ) hours were not significantly differ-

inflow-corrected effluent signals (Wilcoxon signed rank test, $\mathrm{p}<0.001, \mathrm{n}=44)$. In fact, in some cases there was a reduction in TSS concentrations in the effluent relative to the inflow for the non-working period, indicating settling out in the grow-out units overnight.

For most farms, weighted median TSS concentrations exceeded the $80^{\text {th }}$ percentile TSS limit calculated for the reference condition at the point of discharge (Fig. 3a). In addition, 3 farms exceeded the $5 \mathrm{mg} \mathrm{l}^{-1}$ guideline limit for inflow-corrected TSS (Fig. 3b). However, regional median values, i.e. $4.52 \mathrm{mg} \mathrm{l}^{-1}$ for the south coast farms and $3.74 \mathrm{mg}$ $1^{-1}$ for the west coast farms, were within the guideline. The datasets were characterised by consider- ent (paired $t$-test, $\mathrm{p}=0.821, \mathrm{n}=45$ ). Although of less importance than for the particulate fraction, dissolved components were weighted in a similar manner as for TSS. Uncorrected effluent $\mathrm{NH}_{4}{ }^{+}$exceeded the $80^{\text {th }}$ percentile reference level for all farms except Farm I (Fig. 4). However, effluent $\mathrm{NH}_{4}{ }^{+}$levels, uncorrected for inflow concentration (Fig. 4, median = $6.94 \mu \mathrm{mol} \mathrm{N} \mathrm{^{-1 }}$ ), were all well within the $43 \mu \mathrm{mol} \mathrm{N}$ $1^{-1}$ limit.

The other macronutrients were only slightly elevated above inflow values by comparison with $\mathrm{NH}_{4}{ }^{+}$ (Table 2). The inflow-corrected BOD ranged between -0.17 and $3.67 \mathrm{mg} \mathrm{O}_{2} \mathrm{l}^{-1}$, with a median value of $1.31 \mathrm{mg} \mathrm{l}^{-1}$ for the 3 farms at which BOD was measured.

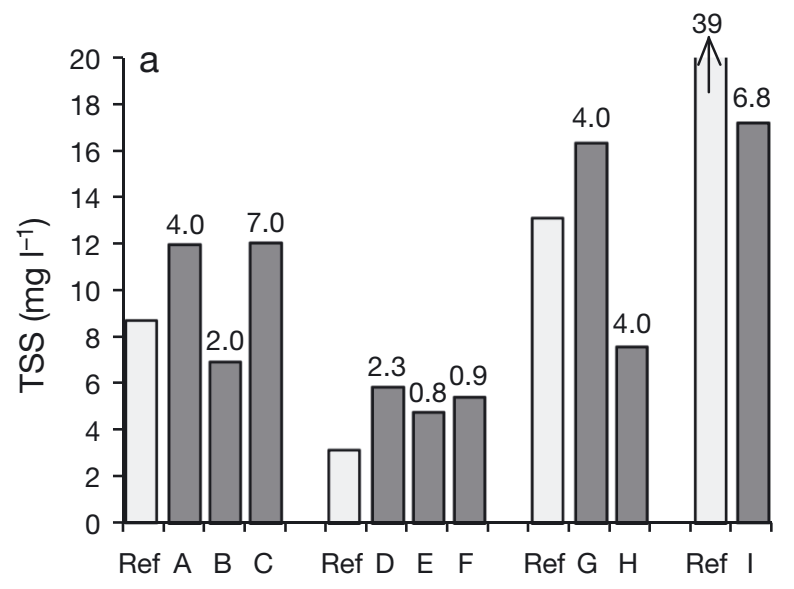

Farm code

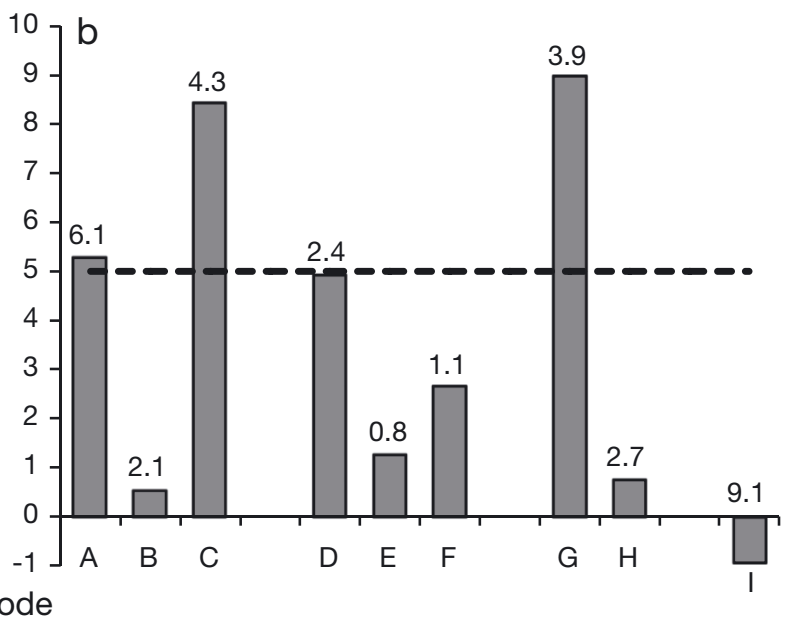

Fig. 3. Median total suspended solid (TSS) concentrations for effluents of south coast (A-F) and west coast abalone farms (G-I). South coast farms are presented separately for Hermanus (A-C) and Gansbaai (D-F). Farm I was operating on partial recirculation. (a) Gross TSS concentrations compared to the $80^{\text {th }}$ percentile (Ref); (b) concentrations in excess of inflow relative to the $5 \mathrm{mg} \mathrm{l}^{-1}$ standard. The numbers above the dark grey bars are the median absolute deviation. The arrow indicates off-scale reading equal to number above it 


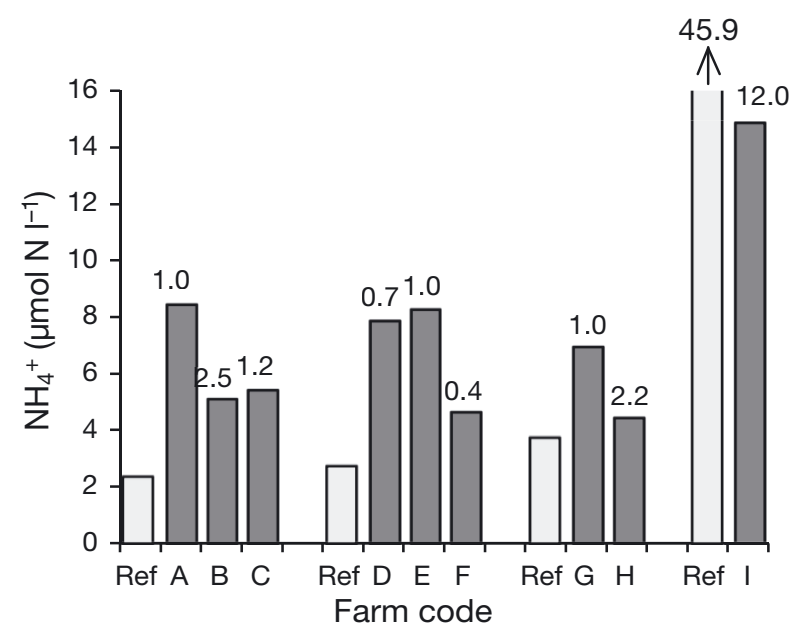

Fig. 4. Median total ammonium $\left(\mathrm{NH}_{4}^{+}\right)$concentrations for effluents of south coast $(\mathrm{A}-\mathrm{F})$ and west coast abalone (Haliotis midae) farms (G-I) compared with the $80^{\text {th }}$ percentile (Ref). South coast farms are presented separately for Hermanus (A-C) and Gansbaai (D-F). Farm I was operating on partial recirculation. The numbers above the dark grey bars are the median absolute deviation. The arrow indicates off-scale reading equal to number above it

\section{Annual loads}

Average effluent concentrations, both uncorrected and inflow-corrected, together with effluent flow rates have been used to calculate mean annual loadings of the various water quality parameters. These have been plotted against abalone production for each farm as estimated from standing stock values (Fig. 5). A mean of each variable (e.g. TSS, $\mathrm{NH}_{4}{ }^{+}$), and estimated production for all sample dates, scaled to an annual production cycle for each farm, was used in these correlations. Calculated absolute TSS loads, corrected for inflow values, range between 17 and $149 \mathrm{mt} \mathrm{yr}^{-1}$ and, with the exclusion of 2 outliers from the south coast, are well correlated with estimated annual abalone production. This relationship gives a specific TSS release of $0.33 \mathrm{mt} \mathrm{TSS} \mathrm{mt} \mathrm{m}^{-1}$ production for the majority of farms. The TSS loads from the 2 outlier farms amount to about $1.4 \mathrm{mt} \mathrm{TSS} \mathrm{mt}^{-1}$ production. The 2 outlier farms (Fig. 5) included those exceeding the $5 \mathrm{mg} \mathrm{l}^{-1}$ limit (Fig. 3b).

As with TSS, nutrient release appeared to be related to abalone biomass/production (Fig. 5). Ammonium dominated in terms of dissolved inorganic $\mathrm{N}$ with a specific $\mathrm{NH}_{4}{ }^{+}$release rate in excess of inflow of $13.2 \mathrm{~kg} \mathrm{~N} \mathrm{mt}^{-1}$ of abalone production. Nitrate discharge was $1.2 \mathrm{~kg} \mathrm{~N} \mathrm{mt}^{-1}$ and nitrite $0.2 \mathrm{~kg} \mathrm{~N} \mathrm{mt}^{-1}$. Although not shown in Fig. 5, production specific $\mathrm{NH}_{4}{ }^{+}$release in excess of inflow appears to be lower for farms using mainly kelp, i.e. all west coast farms (3.8 $\left.\mathrm{kg} \mathrm{mt}^{-1}, \mathrm{r}^{2}=0.731, \mathrm{p}=0.347\right)$ as opposed to arti-
Table 2. Median concentrations of nutrients ( $\mu \mathrm{mol} \mathrm{N}$ or $\mathrm{P}^{-1}$ ) in excess of inflow values for south $(\mathrm{n}=62)$ and west $(\mathrm{n}=28)$ coast abalone farm effluents. The median absolute deviation is given in parentheses

\begin{tabular}{|lcccc|}
\hline & $\mathrm{NH}_{4}{ }^{+}$ & $\mathrm{NO}_{3}{ }^{-}$ & $\mathrm{NO}_{2}{ }^{-}$ & $\mathrm{PO}_{4}{ }^{3-}$ \\
\hline South coast & $3.99(1.71)$ & $0.55(0.53)$ & $0.25(0.09)$ & $0.51(0.21)$ \\
West coast & $2.03(1.59)$ & $1.21(0.80)$ & $0.41(0.18)$ & $0.86(0.34)$ \\
\hline
\end{tabular}

ficial feed, i.e. most south coast farms $\left(18.6 \mathrm{~kg} \mathrm{mt}^{-1}\right.$, $\left.r^{2}=0.652, p=0.098\right)$. However, the relationships were not statistically significant and thus a single value of $13.2 \mathrm{~kg} \mathrm{NH}_{4}{ }^{+}-\mathrm{N} \mathrm{mt}^{-1}$ is applied here for all farms. The outlier in the $\mathrm{NH}_{4}{ }^{+}$regression (Fig. 5) corresponds to Farm $\mathrm{F}$ with seaweed culture integrated into the system. Phosphate loads made up $2.1 \mathrm{~kg} P$ $\mathrm{mt}^{-1}$ abalone production in the effluents, yielding a dissolved inorganic N:P ratio of 6.95 by weight.

\section{Partial nitrogen budget}

For all the farms considered, a substantial proportion of estimated annual inputs as artificial feed/seaweed (Table 3) remained unaccounted for by outputs as abalone harvest and effluent dissolved and particulate components (Table 4). The mean deficits for all farms were $-17.8 \mathrm{~kg} \mathrm{~N} \mathrm{mt}^{-1}(\mathrm{SD}=7.0)$ and $-4.3 \mathrm{~kg} \mathrm{P}^{-}$ $\mathrm{mt}^{-1}(\mathrm{SD}=3.9)$. The same exercise using farm-specific effluent outputs as opposed to the generic relationships given in Fig. 5 resulted in similar mean deficits of $-18.7 \mathrm{~kg} \mathrm{~N} \mathrm{mt}^{-1}(\mathrm{SD}=14.0)$ and $-4.4 \mathrm{~kg} \mathrm{P}$ $\mathrm{mt}^{-1}(\mathrm{SD}=2.5)$. Harvested abalone (Table 4) accounted for $33.0 \%(\mathrm{SD}=4.5 \%$ ) of $\mathrm{N}$ and $12.1 \%$ (SD = $2.3 \%$ ) of $\mathrm{P}$ input as feed. Predominantly kelp fed farms showed significantly greater recoveries of $\mathrm{N}$ $(37.9 \%)$ and $\mathrm{P}(15.1 \%)$ than those using mainly formulated feed, i.e. $30.1 \%$ as $\mathrm{N}$ and $11.8 \%$ as $\mathrm{P}$ ( $t$-test, $\mathrm{p}=0.002$ for $\mathrm{N}$ and $\mathrm{p}=0.039$ for $\mathrm{P}$ ).

\section{DISCUSSION}

\section{Flow rates}

The farm-level specific discharge rates of 8.0 to $18.6 \mathrm{~m}^{3} \mathrm{~h}^{-1} \mathrm{mt}^{-1}$ for the west and south coast facilities, respectively, compares with experimentally determined recommended minimum specific rates of 9.7 to $14.5 \mathrm{l} \mathrm{h}^{-1} \mathrm{~kg}^{-1}$ for small, 20-30 g, Haliotis midae (Yearsley 2007) and 7.2 to $9 \mathrm{l} \mathrm{h}^{-1} \mathrm{~kg}^{-1}$ for larger, 50-60 g, animals (Naylor et al. 2011). The slower 
TSS
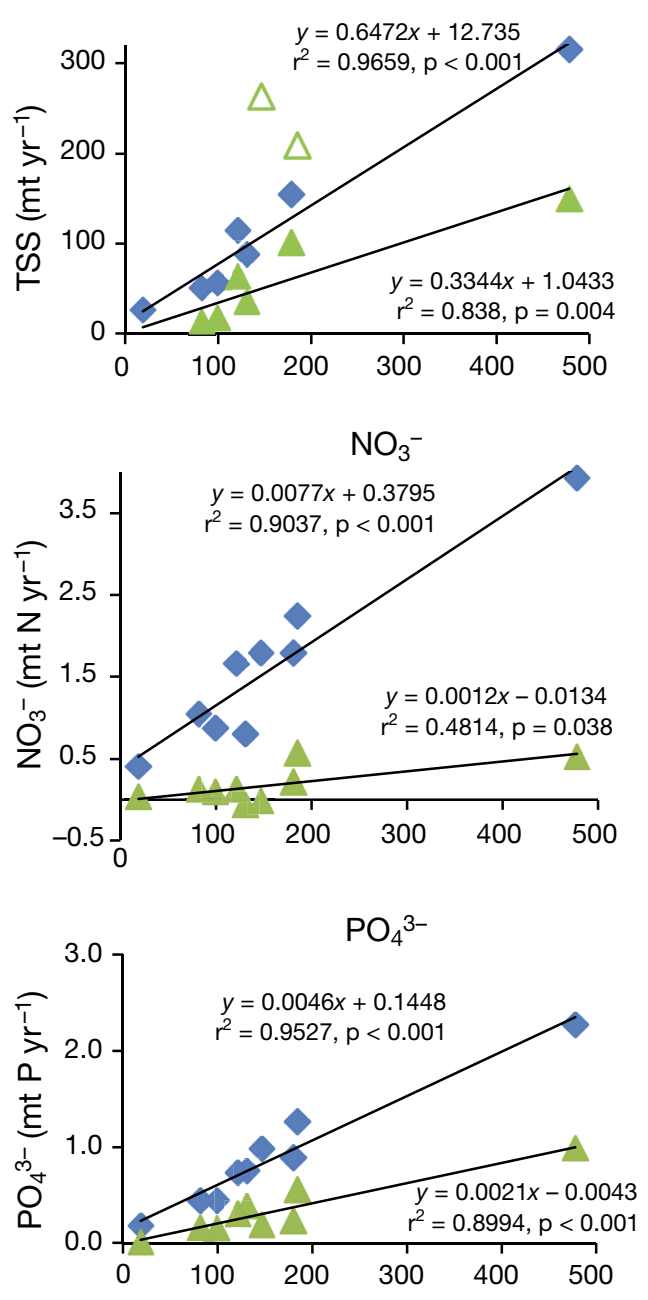
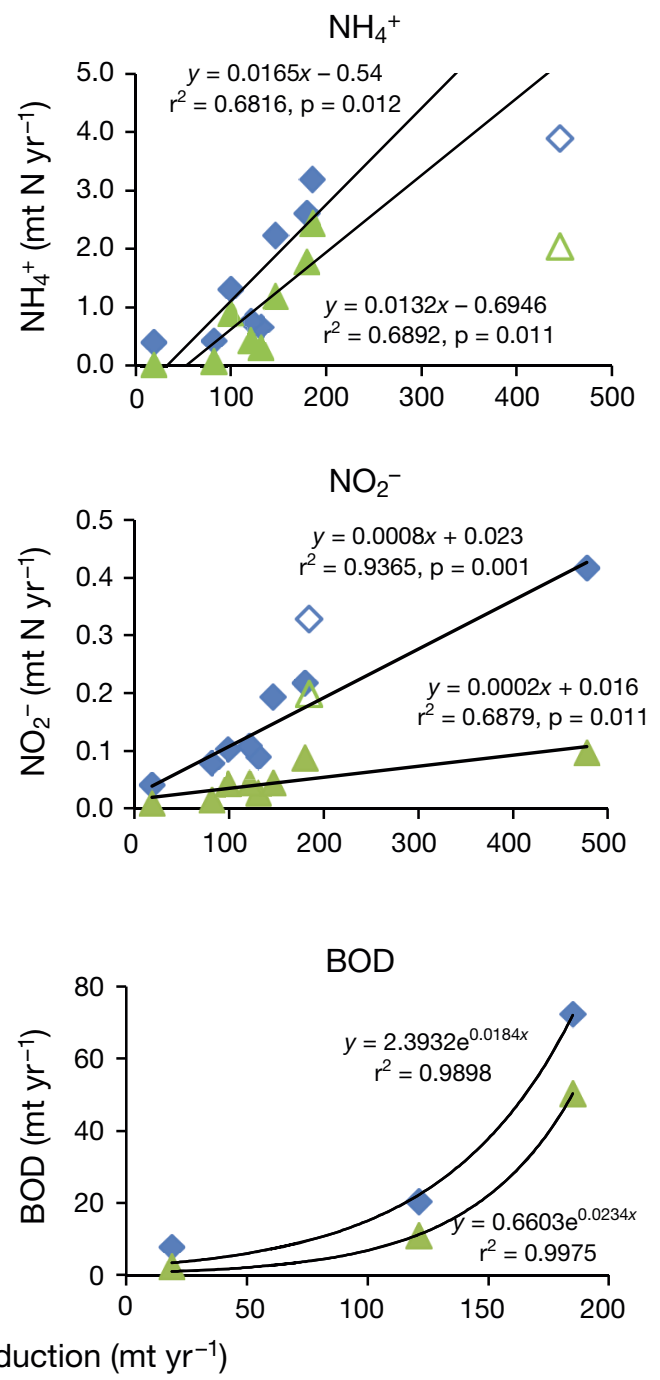

Fig. 5. Mean annual discharge rates of the various water quality variables for each farm, as related to abalone (Haliotis midae) production. Data are presented uncorrected (blue diamonds) and corrected (green triangles) for inflow concentrations. Regression analyses were performed using SigmaPlot 12.0. All linear relationships were significant at the $95 \%$ level. Un-filled symbols represent data excluded from the correlations. TSS: total suspended solids, BOD: biochemical oxygen demand, mt: metric tonnes

turnover rate for the west coast farms may be related to the fact that they were largely kelp-fed during the period of this study. The lower $\mathrm{NH}_{4}{ }^{+}$release expected of abalone raceways maintained on a relatively lowprotein kelp diet would reduce the water turnover required to flush the toxic free ammonia moiety from the growth units (Naylor et al. 2011). The biomassspecific discharge rates measured here translate to an annual production-specific water use of about 85000 to $136000 \mathrm{~m}^{3} \mathrm{mt}^{-1}$ based on P:B ratios of 0.83 and 1.2 for the west and south coast farms, respectively. These water-use indices correspond to some of the highest shown by other land-based aquaculture facilities (Boyd et al. 2007). These rates can be used to estimate future farm waste input scenarios with expansion of the industry.

\section{Water quality}

The marked difference between TSS measured during working and non-working hours illustrates the need to account for variation in farm maintenance activities, particularly cleaning of tanks, in assessing TSS release by abalone farms. Comparison of effluent signals with reference background concentrations for the respective locations showed most farm discharges were in excess of the $80^{\text {th }}$ percentile 
Table 3. Farm $\mathrm{N}$ and $\mathrm{P}$ inputs as artificial feed, kelp Ecklonia maxima and Ulva spp. normalised to production (kg N or P mt ${ }^{-1}$ $\mathrm{yr}^{-1}$ ). For farm inputs, standing stock was converted to production assuming production:biomass ratios of 0.83 and 1.2 for the west and south coast farms, respectively. Commercial artificial feed used by most of the farms was formulated for $34 \%$ protein. The P content of the feed was $0.99 \%$ (T. A. Probyn unpubl. data). Kelp biomass was converted to N and P using a moisture content of $81.95 \%$ and $\mathrm{N}$ and P content of 1.7 and $0.27 \%$ of dry weight, respectively (Smith 2007). Similar calculations for farmed Ulva spp. were based on a moisture content of $85 \%$, protein of $18.31 \%$ (Cyrus et al. 2013) and P content of $0.18 \%$ (RobertsonAndersson et al. 2008)

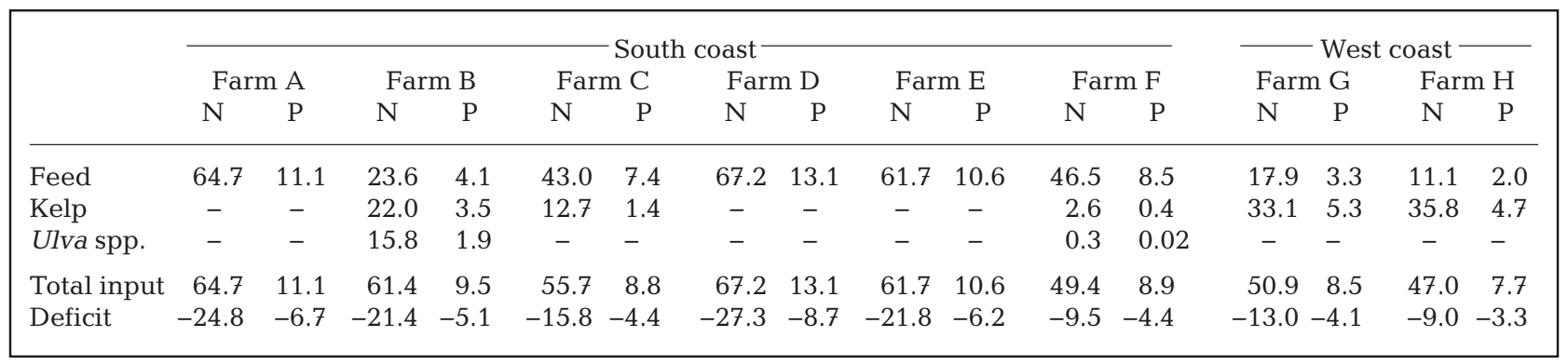

trigger level for TSS at the point of outfall. However, this depiction is misleading in that end-of-pipeline measurements do not account for a mixing zone within which water quality standards may be exceeded. Effluent values were only marginally above the reference condition, implying that such a zone of non-compliance would be very limited in extent. In support, P. J. Britz \& B. P. Godfrey (unpubl. specialist study) showed rapid dilution of dissolved nutrients in an open effluent stream of an abalone farm as it flowed across the intertidal. Initially elevated ammonia concentrations were indistinguishable from background environmental concentrations at the spring low tidal level. Similarly, effects on the intertidal biota gradually attenuated towards the lower intertidal zone (approximately $40 \mathrm{~m}$ from the outfall), with no visual evidence of community effects in the subtidal directly below the effluent stream.

Table 4. Farm N and P outputs normalised to production (kg $\mathrm{N}$ or $\mathrm{P} \mathrm{mt}^{-1}$ ) as calculated for harvested soft tissue/shell and as measured in effluents. Soft tissue moisture $(77.9 \%)$ and protein $(62.3 \%)$ for Haliotis midae is from Britz \& Hecht (1997). Shell moisture (16.51\%) and protein (6.31\%) were calculated from Knauer et al. (1994) assuming soft tissue is $75 \%$ of whole weight (M. Naylor pers. comm.). The P soft tissue $(0.70 \%)$ and shell $(0.022 \%)$ content was as calculated from data in Tan et al. (2001) for H. discus hannai

\begin{tabular}{|lccccc|}
\hline & \multirow{2}{*}{ Coast } & \multicolumn{2}{c}{ Soft tissue } & \multicolumn{2}{c|}{ Shell } \\
& & N & P & N & P \\
\hline Abalone harvest & & 16.5 & 1.2 & 2.1 & 0.06 \\
Net effluent & South & 21.3 & 3.2 & & \\
\multirow{2}{*}{ TOTAL } & West & 19.3 & 3.2 & & \\
& South & 39.9 & 4.4 & & \\
& West & 37.9 & 4.4 & & \\
\hline
\end{tabular}

A more appropriate comparison of effluent TSS is with the abalone standard, which is specific for discharges from abalone farms (Fig. 3b). Although the standard is applied as a single value across all ecosystems, effluent concentrations are corrected for inflow levels and thus do account in a certain manner for natural variability in the indicator. Abalone farm net effluent TSS concentrations (median $4.18 \mathrm{mg} \mathrm{l}^{-1}$ for all farms) is in agreement with that measured at a single South African abalone farm (Yearsley 2007), i.e. $1.64-4.43 \mathrm{mg} \mathrm{l}^{-1}$, and similar to that emanating from land-based trout raceways, $1.9-9.0 \mathrm{mg} \mathrm{l^{-1 }}$ (Viadero et al. 2005, Koçer et al. 2013). These values are considerably less than those for shrimp ponds, which range between 19 and $60 \mathrm{mg} \mathrm{l}^{-1}$ (Páez-Osuna et al. 1997, Casillas-Hernández et al. 2006).

With regard to dissolved nutrients, all farm effluents were well below the recommended $43 \mu \mathrm{mol} \mathrm{l}^{-1}$ $\mathrm{NH}_{4}{ }^{+}$(ASC 2012). These findings indicate the toxicity risk of unionised $\mathrm{NH}_{3}$ is negligible, as free ammonia is only $2-5 \%$ of total $\mathrm{NH}_{4}{ }^{+}$at a typical seawater $\mathrm{pH}$. Ammonium concentrations in excess of inflow (Table 2, median 2.0-4.0 $\mathrm{mmol} \mathrm{l}^{-1}$ ) were similar to that measured at an abalone farm (2.67-3.05 $\mathrm{\mu mol} \mathrm{l}^{-1}$; Yearsley 2007) and semi-intensive shrimp pond effluents $\left(<5 \mu \mathrm{mol} \mathrm{l}{ }^{-1}\right.$; Páez-Osuna et al. 1997, CasillasHernández et al. 2006) but generally substantially less than that for intensive shrimp ponds (Briggs \& Funge-Smith 1994, Páez-Osuna 2001) and trout raceways (Boaventura et al. 1997, Viadero et al. 2005, Koçer et al. 2013) where concentrations 1-2 orders of magnitude higher are not uncommon. The other nutrients were only marginally elevated above background as has been measured for other flow-through aquaculture operations (e.g. Páez-Osuna et al. 1997, Koçer et al. 2013) and as such pose little risk of 
Table 5. Comparison of net discharges per metric tonne of production of total suspended solids (TSS), $\mathrm{NH}_{4}{ }^{+}-\mathrm{N}_{1} \mathrm{PO}_{4}{ }^{3-}-\mathrm{P}$, total N (TN) and total P (TP) for some land-based aquaculture facilities

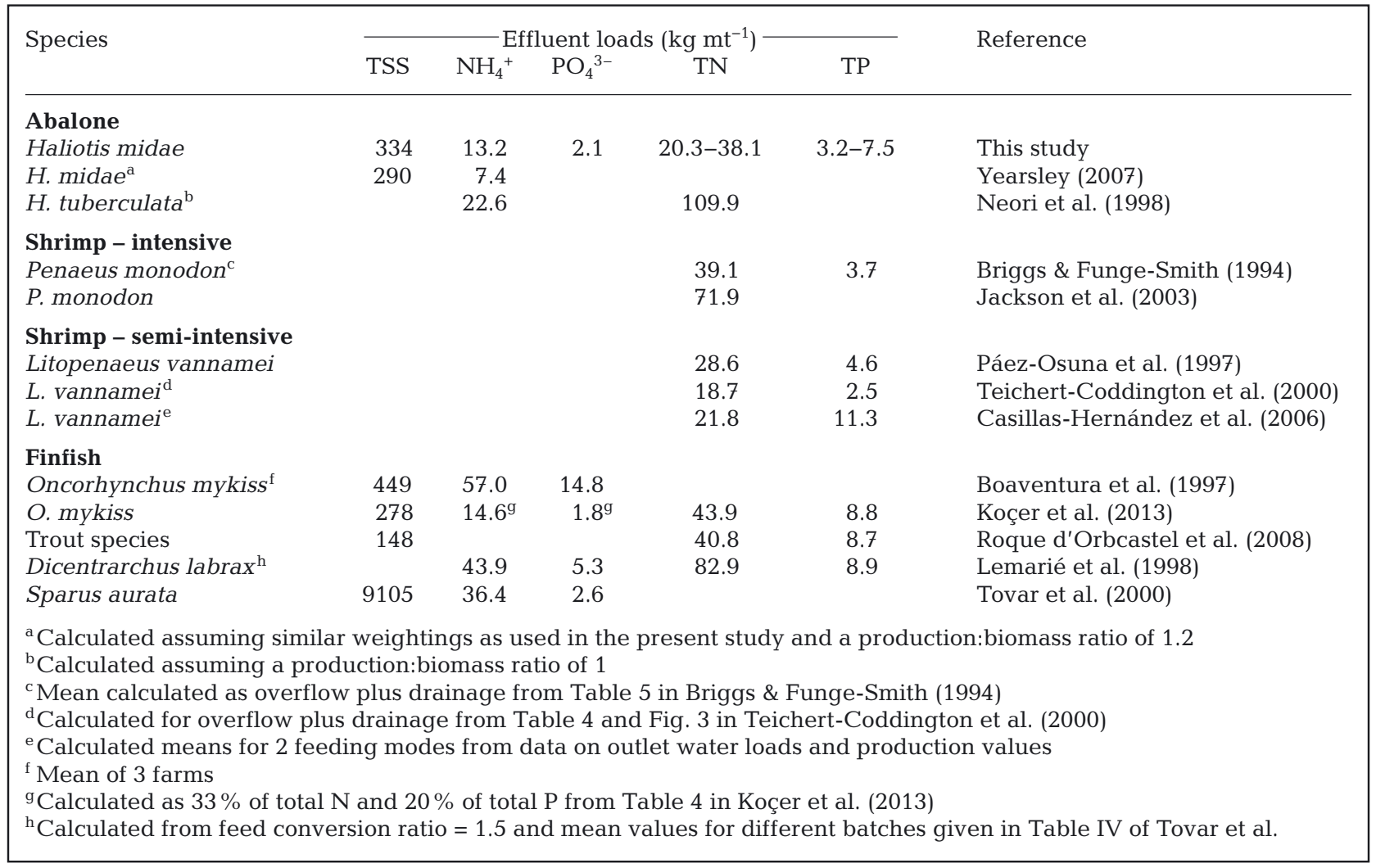

eutrophication. As with TSS, the BOD of $1.31 \mathrm{mg} \mathrm{l}^{-1}$ for the 3 farms is at the low end of the range reported for trout farms, 0.4-14 $\mathrm{mg} \mathrm{l}^{-1}$ (Boaventura et al. 1997, Viadero et al. 2005, Koçer et al. 2013) and well below maximum levels in shrimp pond effluents (PáezOsuna 2001). The Global Aquaculture Alliance Best Aquaculture Practices certification standards for finfish and crustaceans have a target effluent BOD of $30 \mathrm{mg} \mathrm{l}^{-1}$ (subsequent to an initial value of $50 \mathrm{mg} \mathrm{l}^{-1}$ ), further illustrating the benign nature of abalone farm effluents (GAA 2016). Given the limited sample size at present and the sometimes high variability in indicator values (Figs. $3 \& 4$ ), additional sampling will better constrain these values, particularly with regard to TSS.

Results obtained in this study indicate that effluents from land-based abalone farms constitute a relatively low-risk threat to coastal receiving waters. However, the use of indicator concentrations as the measure of effluent quality has been subject to some criticism as it is possible to achieve compliance with numerical water quality criteria by increasing the volume of water passing through a farm to facilitate dilution. Using a load-based approach precludes such pseudo-mitigation measures and provides a more meaningful indication of potential impact on the receiving environment. As absolute loads of pollutants from aquaculture are highly dependent on standing stock/production and feeding regimens, a common approach is to normalise to production (Boyd et al. 2007). The abalone production-specific TSS value excluding outliers of $334 \mathrm{~kg}$ TSS $\mathrm{mt}^{-1}$ measured in this study is in general agreement with what has been measured for some other land-based aquaculture operations, whereas the production-specific loadings of $13.2 \mathrm{~kg} \mathrm{NH}_{4}{ }^{+}-\mathrm{N} \mathrm{mt}^{-1}$ and $2.1 \mathrm{~kg}$ $\mathrm{PO}_{4}{ }^{3-}-\mathrm{P} \mathrm{mt}{ }^{-1}$ are somewhat lower (Table 5).

\section{Total $\mathbf{N}$ and total $\mathbf{P}$}

Farm activities significantly enrich discharged particulate matter relative to inflow in organics, $\mathrm{N}$ and $\mathrm{P}$, most noticeably particulate $\mathrm{N}$ (Table 1 ). The mean particulate $\mathrm{N}(\mathrm{PN})$ concentration in south and west coast abalone farm effluents was $2.02 \%$ and $1.43 \%$ dry weight, respectively (Table 1). Based on the production-specific TSS release rates of $334 \mathrm{~kg} \mathrm{TSS} \mathrm{mt}^{-1}$, 
one can estimate a PN release of 6.7 and $4.7 \mathrm{~kg} \mathrm{~N}$ $\mathrm{mt}^{-1}$ abalone production. By comparison, the dissolved inorganic $\mathrm{N}$ (DIN) loading was $14.6 \mathrm{~kg} \mathrm{~N} \mathrm{mt}^{-1}$, of which $\mathrm{NH}_{4}{ }^{+}$was the most important (Fig. 5). Combining PN and DIN gives estimates of total $\mathrm{N}(\mathrm{TN})$ of $21.3 \mathrm{~kg} \mathrm{~N} \mathrm{mt}^{-1}$ abalone production for south coast farms and $19.3 \mathrm{~kg} \mathrm{~N} \mathrm{mt}^{-1}$ for the west coast (mean $20.3 \mathrm{~kg} \mathrm{~N} \mathrm{mt}^{-1}$ for all farms). These values are underestimates in that the contribution of dissolved organic $\mathrm{N}$ (DON) was not taken into account. Neori et al. (1998) showed that DON can contribute nearly $50 \%$ to the TN in H. tuberculata effluents. A high proportion of DON (34\%) has similarly been reported for European seabass (Lemarié et al. 1998). Assuming the $\mathrm{N}$ deficit identified in Table 3 (mean $17.8 \mathrm{~kg} \mathrm{~N}$ $\mathrm{mt}^{-1}$ ) resides in the unmeasured dissolved organic fraction, $\mathrm{TN}$ increases to $38.1 \mathrm{~kg} \mathrm{~N} \mathrm{mt}^{-1}$. The range in TN calculated for $H$. midae farms is in general agreement with that reported for other land-based aquaculture operations (Table 5).

Open water finfish aquaculture systems tend to impose slightly higher nutrient loads on the environment. Nitrogen loads calculated from mass balance and bioenergetics models for open water finfish systems include $50-54.2 \mathrm{~kg} \mathrm{~N} \mathrm{mt}{ }^{-1}$ for Norwegian salmon and rainbow trout farms (Azevedo et al. 2011, Wang et al. 2012), and $66.2-86.9 \mathrm{~kg} \mathrm{~N} \mathrm{mt}^{-1}$ for nonsalmonids (Gillibrand et al. 2002, Davies \& Slaski 2003). As an extreme comparison, model predictions for farmed southern bluefin tuna, characterised by extremely high metabolic rates and fed an un-optimised diet of baitfish, reveal high environmental losses of the order of $260-505 \mathrm{~kg} \mathrm{~N} \mathrm{mt}^{-1}$ production (Fernandes et al. 2007).

Similar calculations with $\mathrm{P}$ yield $2.1 \mathrm{~kg} \mathrm{PO}_{4}{ }^{3-}$ $\mathrm{P} \mathrm{mt}^{-1}$ and $1.1 \mathrm{~kg}$ particulate $\mathrm{P} \mathrm{mt}^{-1}$ production based on Fig. 5 and Table 1. Thus, the total P (TP) discharge by abalone is estimated at $3.2-7.5 \mathrm{~kg} \mathrm{P} \mathrm{mt}^{-1}$, with the upper limit incorporating the $\mathrm{P}$ deficit based on budget calculations (Table 3). As with $\mathrm{N}$, TP discharge rates are similar to what have been reported for other land-based aquaculture facilities (Table 5). Open water systems have similar TP release rates, e.g. $9.3 \mathrm{~kg} \mathrm{P} \mathrm{mt}^{-1}$ for Norwegian salmon farms (Wang et al. 2012) and 7.5-15.2 kg P mt ${ }^{-1}$ for freshwater rainbow trout (Bureau et al. 2003, Azevedo et al. 2011).

The ratio in which macronutrients are available has been regarded as important to coastal ecosystems both from the perspective of phytoplankton assemblages/harmful algal blooms and stoichiometric regulation of food webs (Heisler et al. 2008, Glibert et al. 2011). In addition, the form in which a particular nutrient is available, i.e. either dissolved or particulate, organic or inorganic, reduced or oxidised inorganic, can influence phytoplankton community structure. The discharged TN:TP ratio of 5.1-6.3 is somewhat less than the Redfield ratio of 7.2 by weight. This compares with a range for finfish of 5.4-9.3 for rainbow trout (Koçer et al. 2013) and seabass (Lemarié et al. 1998), respectively, and 5.5-7.3 for shrimp (Teichert-Coddington et al. 2000, Casillas-Hernández et al. 2006). The slightly lower TN:TP ratio for abalone than other farmed species suggests greater $\mathrm{N}$ retention within these farm systems. This relative excess of $\mathrm{P}$ is further illustrated by the poor recovery of dietary $\mathrm{P}(13 \%)$ relative to $\mathrm{N}$ $(33 \%)$ in abalone harvest. The $\mathrm{N}$ accretion value is similar to some of the higher values recorded for finfish (Hargreaves 1998, Wang et al. 2012) and semiintensive shrimp culture, even if fertiliser input is included (Teichert-Coddington et al. 2000, CasillasHernández et al. 2006). Nitrogen recovery in intensive shrimp farms may be less (e.g. Briggs \& FungeSmith 1994, Jackson et al. 2003). The proportion of dietary $\mathrm{P}$ recovered in abalone harvest is generally lower than for fish $(27-31 \%$; Lemarié et al. 1998, Wang et al. 2012) and shrimp (19-25\%; TeichertCoddington et al. 2000, Casillas-Hernández et al. 2006). The poorer accrual of artificial feed $P$ relative to kelp is probably related to the fact that abalone are slow feeders, and P leaching rates from artificial feed may be high (Tan et al. 2001, Sales et al. 2003).

It is now established that non-symbiotic diazotrophy is not limited to open ocean environments but occurs in coastal upwelling environments through the action of heterotrophic bacteria (Fernandez et al. 2015). The slight excess of $P$ calculated for abalone farm effluents could theoretically promote $\mathrm{N}_{2}$ fixation. However, given the fact that abalone farm input of nutrients is a minor to insignificant fraction of natural fluxes, as will be shown in the following section, it is highly unlikely they will exert major ecosystem effects beyond the near field.

A load-based approach as presented here could provide the most effective means of environmental protection, where marked departures from an industry achievable standard as given by the relationships in Fig. 5 (e.g. TSS) could be used to initiate technological or management interventions at individual farms. Such an approach also allows one to project waste loads that could be imposed on receiving water bodies through expansion of production without resorting to extensive effluent monitoring (Boyd et al. 2007). In addition, as best management practices and improved technologies are increasingly ex- 
ploited by industry, the requirement for compliance monitoring could be reduced dramatically.

\section{Comparison with other inputs}

Aquaculture waste loads are often compared with other more common sources of pollution such as domestic sewage to provide a framework that is more easily understood by the broader stakeholder community. Discharges from aquaculture can thus be converted to human population equivalents to provide a common currency for application to specific indicators. The estimated per capita excretion of $\mathrm{N}$ in urine and faeces for South Africa is $3.4 \mathrm{~kg} \mathrm{~N}_{\text {person }}{ }^{-1}$ $\mathrm{yr}^{-1}$ (Jönsson et al. 2004). Human population equivalents can be calculated from the abalone production values of $1106 \mathrm{mt} \mathrm{yr}^{-1}$ for the south coast and $128 \mathrm{mt}$ $\mathrm{yr}^{-1}$ for the west coast (Dept of Agriculture Forestry and Fisheries unpubl. data), and TN release values reported in the previous section. After correcting for the fact that only $64 \%$ of particulate matter in abalone farm effluent is organic (Table 1), the approximate water pollution load of the south coast abalone farms is equivalent to excretion by $6100-$ 11900 people. For west coast farms, the population equivalent in terms of $\mathrm{N}$ is $660-1300$ people. Thus the human population equivalents per $\mathrm{mt}$ of abalone is approximately $5.4-10.6$ as an average for both west and south coast farms. This range of $\mathrm{N}$-specific pollutant loads, though highly speculative, is comparable to that calculated for closed system shrimp farms and raceway production of trout, i.e. 4.2 and 11.9, respectively (Boyd et al. 2007).

The above approach does allow comparison between different sources of pollution but does not fully consider natural sources of the various indicators. In addition, the use of variables based on concentration, although corrected for background or inflow levels, do not explicitly account for natural supply rates. To place abalone aquaculture discharges in a more ecological perspective, a brief comparison is provided with estimated natural supply rates of TSS and $\mathrm{NH}_{4}{ }^{+}$ to the inshore environment. These comparisons are made at the broader ecosystem level and thus address the cumulative impacts from a number of farms.

The farms considered in this study are all located in the productive Benguela upwelling system, characterised by high nutrient input and extensive kelp beds. Kelps typically introduce large quantities of particulate organic matter (POM) to the coastal zone from the erosion of their blades. Newell \& Field (1983) have shown that kelp plus understory algae produce $2.81 \mathrm{~kg}$ dry matter $\mathrm{m}^{-2} \mathrm{yr}^{-1}$, of which $70 \%$ is released as POM. The south and west coast farms fall in 2 kelp concession areas; Area 6 and Area 11 of 682 ha and 618 ha in extent, respectively (Anderson et al. 2007). Using the above data, one can calculate the total annual production of POM by kelp beds as $13429 \mathrm{mt} \mathrm{yr}^{-1}$ (south coast, Area 6) and $12169 \mathrm{mt} \mathrm{yr}^{-1}$ (west coast, Area 11). Based on actual annual abalone production data for 2013 of $1106 \mathrm{mt}$ for the south coast farms and $128 \mathrm{mt}$ for the west coast, and using the correlation between production and TSS load (Fig. 5), the estimated annual TSS release from the abalone farms is $369 \mathrm{mt} \mathrm{yr}^{-1}$ (south) and $43 \mathrm{mt} \mathrm{yr}^{-1}$ (west). Thus, for the majority of farms, TSS discharges amount to about $2.8 \%$ (south) and $0.35 \%$ (west) of the natural production of POM from kelp beds in the 2 areas. For the outlier farms these proportions are 11 and $1.4 \%$, respectively.

Similar calculations can be done for a local scale using a different dataset. Levitt et al. (2002) showed that the kelp beds on the northern and southern parts of Danger Point, Gansbaai, occupy approximately 336 ha of the immediate sub-tidal zone extending along $16 \mathrm{~km}$ of coastline. The standing stock of kelp in this area is given as $22973 \mathrm{mt}$ wet weight, which corresponds to $3192 \mathrm{mt}$ dry weight using a conversion factor of wet to dry of 7.14 for kelp fronds, as calculated from data in Field et al. (1980). Applying a kelp P:B ratio of 3.5 (R. Anderson pers. comm.) and $70 \%$ release of POM (Newell \& Field 1983), gives $7822 \mathrm{mt} \mathrm{POM} \mathrm{yr}{ }^{-1}$. The release of TSS by farms in the Gansbaai area (160 $\mathrm{mt} \mathrm{yr}^{-1}$ ) can thus be estimated as $2.3 \%$ of this value; similar to what was calculated for the broader Concession Area 6. If one assumes that the major zone of influence of farm-based TSS is restricted to $1 \mathrm{~km}$ of the coastline, the proportional contribution of the Gansbaai farms increases 5-fold to $12.3 \%$ of natural release from kelp, for an equivalent length of coastline. Increasing the assumed zone of influence for a farm decreases the calculated relative input. Given the highly exposed nature of both the west and south coast farms, the assumption of a $1 \mathrm{~km}$ length scale for a farm is likely to be highly conservative.

Equivalent comparisons can be made with the dissolved components of abalone farm effluents. Upwelling of cold, deep waters in response to equatorward winds introduces high concentrations of $\mathrm{NO}_{3}{ }^{-}$ (and other nutrients) into the near-shore southern Benguela environment. Model-derived annual mean volume flux for the Cape Peninsula (lowest of the major upwelling cells within the Benguela) is $0.07 \mathrm{~Sv}$ $\left(\mathrm{Sv}=10^{6} \mathrm{~m}^{3} \mathrm{~s}^{-1}\right)$ for a coastline length of $111 \mathrm{~km}$ 
(Veitch et al. 2009). Assuming a typical source water concentration of $20 \mathrm{mmol} \mathrm{m}^{-3} \mathrm{NO}_{3}^{-}$, this volume flux translates to $5569 \mathrm{~kg} \mathrm{~N} \mathrm{~m}^{-1} \mathrm{yr}^{-1}$ (or $\mathrm{mt} \mathrm{N} \mathrm{km}^{-1} \mathrm{yr}^{-1}$ ). Adopting the nominal $1 \mathrm{~km}$ length scale for the zone of farm influence means $5569 \mathrm{mt} \mathrm{N}$ farm ${ }^{-1} \mathrm{yr}^{-1}$. By comparison, estimated dissolved $\mathrm{N}$ discharges, based on regional production figures, range between $9.4 \mathrm{mt}$ $\mathrm{N} \mathrm{yr}^{-1}$ for all 6 south coast farms, and $1.9 \mathrm{mt} \mathrm{N} \mathrm{yr}^{-1}$ for the 3 smaller west coast farms. Clearly, coastal upwelling influences a much wider shelf region than one could expect for farm discharges and as such, the above comparison is somewhat artificial. However, these calculations do serve to illustrate the insignificance of the estimated total annual dissolved $\mathrm{N}$ release from all abalone farms, predominantly as $\mathrm{NH}_{4}{ }^{+}$ ( $90 \%$ of inorganic), in the context of the larger ecosystem. On an individual farm basis, $\mathrm{N}$ input to the coastal zone as inorganic dissolved $\mathrm{N}$ from abalone farms can be estimated as $0.01-0.05 \%$ of the $\mathrm{N}$ introduced as $\mathrm{NO}_{3}{ }^{-}$by upwelling over a nominal coastline length, i.e. $1 \mathrm{~km}$. Equivalent calculations with $\mathrm{PO}_{4}{ }^{3-}$ at $2 \mathrm{mmol} \mathrm{m}^{-3}$ show a similar farm contribution of $0.01-0.03 \%$ of that introduced by upwelling.

\section{Carbon footprint}

The overall industry water-use index of $85000-$ $136000 \mathrm{~m}^{3} \mathrm{mt}^{-1}$ produced is indicative of a high specific energy cost. The mean installed pump capacity for the South African abalone industry in 2007 was equivalent to $2.8 \mathrm{~kW} \mathrm{mt}^{-1}$ of production, with a range of 1.4-5.5 kW mt ${ }^{-1}$, depending on local geomorphology (W. Barnes, Abalone Farmers Association, pers. comm.). An additional $2.2 \mathrm{~kW} \mathrm{mt}^{-1}$ production was used for aeration. The total direct electricity usage of $5 \mathrm{~kW} \mathrm{mt}^{-1}$ is equivalent to $43.8 \mathrm{kWh} \mathrm{kg}^{-1}$ over an annual production cycle. By comparison, direct energy inputs for semi-intensive shrimp farms are smaller at about $15 \mathrm{kWh} \mathrm{kg}^{-1}$ of a total energy input of 44-47 $\mathrm{kWh} \mathrm{kg}^{-1}$ (Troell et al. 2004, Bunting \& Pretty 2007). The energy usage for abalone can be converted to $\mathrm{CO}_{2}$ equivalents using the national conversion factor of $1.01 \mathrm{~kg} \mathrm{CO} \mathrm{kWh}^{-1}$ for 2014-2015 (see www.eskom.co.za). This conversion factor is one of the highest worldwide, as South Africa derives most of its central grid electricity from coal-fired power stations. Thus the direct energy inputs for water and aeration impose a relatively high production-specific $\mathrm{C}$ footprint for abalone of about $44 \mathrm{~kg}$ $\mathrm{CO}_{2} \mathrm{~kg}^{-1}$. Prior calculations for a South African abalone farm yield an even higher estimated $\mathrm{C}$ emission of $97 \mathrm{~kg} \mathrm{CO}_{2} \mathrm{~kg}^{-1}$ when operating in monocul- ture (Nobre et al. 2010). By comparison, C footprints of $11.7 \mathrm{~kg} \mathrm{CO}_{2} \mathrm{~kg}^{-1}$ (Bunting \& Pretty 2007) and $10.9 \mathrm{~kg} \mathrm{CO}_{2} \mathrm{~kg}^{-1}$ (Troell et al. 2004) have been calculated for shrimp farms.

Although direct electricity usage is likely to be a major energy input in abalone farming, other operational activities such as the production of feed and seed as well as indirect energy inputs associated with fixed infrastructure will need to be taken into account for a more rigorous energy inventory. Nevertheless, the above production-specific $\mathrm{CO}_{2}$ emission gives an industry $\mathrm{C}$ footprint of $65000 \mathrm{mt} \mathrm{CO}_{2}$, based on 2013 abalone production of $1470 \mathrm{mt}$ (DAFF 2014). This compares with an average total $\mathrm{C}$ footprint for livestock in South Africa of about 30 million $\mathrm{mt} \mathrm{CO}_{2}$ equivalents for 2000-2010 (DEA 2013). Although underestimated to the extent that only direct energy usage by the industry was considered, the abalone farming sector is currently too small to make a significant contribution to the national $\mathrm{C}$ footprint. Although there are a number of constraints to the continued development of the industry such as availability of feed and concerns over China flooding the market, projections are optimistic failing any major global economic downturn (Cook 2014). Given current trends in the South African farmed abalone industry (DAFF 2014), farmed production in 2013 could double by 2018 or reach $10000 \mathrm{mt}$ by 2030 .

\section{SUMMARY AND CONCLUSIONS}

The $80^{\text {th }}$ percentile background reference level to end-of-pipeline discharges proved unsatisfactory as a guideline. This finding is not surprising given that the appropriate application of this reference level requires consideration of a mixing zone. However, environmental sampling around a discharge is often logistically challenging and, in the case of a highly exposed coastline characteristic of the South African situation, potentially hazardous. The ASC (2012) standards are thus preferred as a regulatory goal.

Concentrations of the various water quality parameters, particularly $\mathrm{NH}_{4}{ }^{+}$and TSS, were generally lower than measured in other land-based farms such as finfish and shrimp. However, abalone farms are characterised by very high water use indices, resulting in production-specific loadings of TSS, TN and TP that were similar to those measured for other operations. This requirement for rapid water turnover also imposes a high specific energy demand on individual farms with implications regarding the industry-specific C footprint. 
Our results show that environmental risk posed by farm-derived $\mathrm{NH}_{4}{ }^{+}$and the other dissolved inorganic nutrients was minimal, particularly for a coastal upwelling environment where natural inputs of nutrients are overwhelmingly predominant. The requirement for regulatory monitoring of $\mathrm{NH}_{4}{ }^{+}$at abalone farms in this environment, as a stressor itself or as an indicator for other nutrients, is thus debatable. Similarly, farmderived TSS for the most part constituted only a small proportion $(0.35-2.8 \%)$ of that calculated for natural particulate release from the ubiquitous kelp beds occurring along the coastline. Assuming an average TSS concentration of double the limit, i.e. $10 \mathrm{mg} \mathrm{l}^{-1}$, the calculated annual TSS load based on 2013 abalone production amounts to only 1-11\% of that generated from kelp beds in the west and south coastal nodes, respectively. This suggests that there may well be scope for relaxing the $5 \mathrm{mg} \mathrm{l}^{-1}$ limit where natural POM loads are high. Such an approach would need to address the cumulative impact of changing production scenarios within regional nodes.

Acknowledgements. We thank the following industry members for their cooperation and assistance in collecting samples and providing ancillary data: Matt Naylor, Dennis Whyte, Wayne Barnes, Hymne Ferreira, Barend Stander, Stoffel van Dyke, Johann Beets, Rowan Yearsley, Mike Gray, Roderick Donald, Rowan Timer, Steyn Miller, Izak Otto, Deidre Du Toit, Jonathan Venter, James LawsonSmith, J. P. Coetzer, Peter Pesch, and S. van der Merwe.

\section{LITERATURE CITED}

Anderson RJ, Rand A, Rothman MD, Share A, Bolton JJ (2007) Mapping and quantifying the South African kelp resource. Afr J Mar Sci 29:369-378

ANZECC \& ARMCANZ (Australian and New Zealand Environment and Conservation Council and Agriculture and Resource Management Council of Australia and New Zealand) (2000) Australian and New Zealand guidelines for fresh and marine water quality. National Water Quality Management Strategy Paper No 4. ANZECC \& ARMCANZ, Canberra

ASC (Aquaculture Stewardship Council) (2012) ASC abalone standard-Version 1, Jan 2012. www.asc-aqua. org/upload/ASC\%20Abalone\%20Standard_v1.0.pdf (accessed 12 April 2013)

Azevedo PA, Podemski CL, Hesslein RH, Kasian SEM, Findlay DL, Bureau DP (2011) Estimation of waste outputs by a rainbow trout cage farm using a nutritional approach and monitoring of lake water quality. Aquaculture 311: 175-186

Boaventura R, Pedro AM, Coimbra J, Lencastre E (1997) Trout farm effluents: characterization and impact on the receiving waters. Environ Pollut 95:379-387

Boyd C, Tucker C, McNevin A, Bostick K, Clay J (2007) Indicators of resource use efficiency and environmental performance in fish and crustacean aquaculture. Rev Fish
Sci 15:327-360

Briggs MRP, Funge-Smith SJ (1994) A nutrient budget of some intensive marine shrimp ponds in Thailand. Aquacult Fish Manag 25:789-811

Britz PJ, Hecht T (1997) Effect of dietary protein and energy level on growth and body composition of South African abalone, Haliotus midae. Aquaculture 156:195-210

Bunting S, Pretty J (2007) Aquaculture development and global carbon budgets: Emissions, sequestration and management options. Center for Environment and Society Occasional Paper 2007-1. University of Essex. www.essex.ac.uk/ces/esu/occ-papers.shtm (accessed 14 November 2016)

Bureau DP, Gunther SJ, Cho CY (2003) Chemical composition and preliminary theoretical estimates of waste outputs of rainbow trout reared in commercial cage culture operations in Ontario. N Am J Aquacult 65:33-38

Burkholder JM, Shumway SE (2011) Bivalve shellfish aquaculture and eutrophication. In: Shumway SE (ed) Shellfish aquaculture and the environment. John Wiley \& Sons, Chichester, p 155-215

Carpenter JH (1965) The Chesapeake Bay Institute method for the Winkler dissolved oxygen titration. Limnol Oceanogr 10:141-143

* Casillas-Hernández R, Magallón-Barajas F, Portillo-Clarck G, Páez-Osuna F (2006) Nutrient mass balances in semiintensive shrimp ponds from Sonora, Mexico using two feeding strategies: trays and mechanical dispersal. Aquaculture 258:289-298

Cook PA (2014) The worldwide abalone industry. Mod Econ 5:1181-1186

* Cyrus MD, Bolton JJ, De Wet L, Macey BM (2013) The development of a formulated feed containing Ulva (Chlorophyta) to promote rapid growth and enhanced production of high quality roe in the sea urchin Tripneustes gratilla (Linnaeus). Aquacult Res 45:159-176

DAFF (Department of Agriculture, Forestry and Fisheries) (2014) Aquaculture yearbook South Africa 2014. DAFF, Rogge Bay, Cape Town

*Davies IM, Slaski RJ (2003) Waste production by farmed Atlantic halibut (Hippoglossus hippoglossus L.). Aquaculture 219:495-502

DEA (Department of Environment Affairs) (2013) GHG inventory report for South Africa 2000-2010. https:// www.environment.gov.za/sites/default/files/docs/green housegas_invetorysouthafrica.pdf (accessed 18 May 2016)

Delzer GC, McKenzie SW (2003) Five-day biochemical oxygen demand: U.S. Geological Survey techniques of water-resources investigations, Book 9, 3rd edn. http: //pubs.water.usgs.gov/twri9A/ (accessed 25 May 2016)

DWAF (Department of Water Affairs and Forestry) (1995) South African water quality guidelines for coastal marine waters. Vol 1: Natural environment. DWAF, Pretoria

Fernandes M, Lauer P, Cheshire A, Angove M (2007) Preliminary model of nitrogen loads from southern bluefin tuna aquaculture. Mar Pollut Bull 54:1321-1332

*Fernandez C, González ML, Mu oz C, Molina V, Farias L (2015) Temporal and spatial variability of biological nitrogen fixation off the upwelling system of central Chile (35-38.5 ${ }^{\circ}$ S). J Geophys Res 120:3330-3349

Field JG, Griffiths CL, Griffiths RJ, Jarman N, Zoutendyk P, Velimirov B, Bowes A (1980) Variation in structure and biomass of kelp communities along the South-West Cape coast. Trans R Soc S Afr 44:145-203

Francis TL, Maneveld GW, Venter J (2008) Growth of mar- 
ket-size abalone (Haliotis midae) fed kelp (Ecklonia maxima) versus a low-protein commercial feed. Afr J Aquat Sci 33:279-282

Gillibrand PA, Gubbins MJ, Greathead C, Davies IM (2002) Scottish executive locational guidelines for fish farming: predicted levels of nutrient enhancement and benthic impact. Scottish Fisheries Research Report No. 63/2002. Scottish Fisheries Research Services, Aberdeen

Glibert PM, Fullerton D, Burkholder JM, Cornwell JC, Kana T (2011) Ecological stoichiometry, biogeochemical cycling, invasive species, and aquatic food webs: San Francisco estuary and comparative systems. Rev Fish Sci 19: $358-417$

Global Aquaculture Alliance (2016) Finfish and crustacean farms. BAP standards, guidelines, Issue 2. http://bap. gaalliance.org/wp-content/uploads/sites/2/2015/02/BAP -FishCrustF-416_.pdf (accessed 21 August 2016)

Grasshoff K, Ehrhardt M, Kremling K (eds) (1983) Methods of seawater analysis, $2^{\text {nd }}$ edn. Verlag Chemie, Weinheim

Hargreaves JA (1998) Nitrogen biogeochemistry of aquaculture ponds. Aquaculture 166:181-212

Hargreaves JA (2011) Molluscan shellfish aquaculture and best management practices. In: Shumway SE (ed) Shellfish aquaculture and the environment. John Wiley \& Sons, Chichester, p 51-80

Heisler J, Glibert PM, Burkholder JM, Anderson DM and others (2008) Eutrophication and harmful algal blooms: a scientific consensus. Harmful Algae 8:3-13

Jackson C, Preston N, Thompson PJ, Burford M (2003) Nitrogen budget and effluent nitrogen components at an intensive shrimp farm. Aquaculture 218:397-411

Jönsson H, Richert Stinzing A, Vinnerås B, Salomon E (2004) Guidelines on the use of urine and faeces in crop production. Report 2004-2. EcoSanRes Programme. Stockholm Environment Institute, Stockholm

Knauer J, Hecht T, Duncan JR (1994) Proximate composition of the South African abalone Haliotis midae (Haliotidae, Gastropoda). Aquacult Fish Manag 25:351-354

Koçer MAT, Kanyilmaz M, Yilayaz A, Sevgili H (2013) Waste loading into a regulated stream from land-based trout farms. Aquacult Environ Interact 3:187-195

* Lemarié G, Martin JLM, Dutto G, Garidou C (1998) Nitrogenous and phosphorous waste production in a flowthrough land-based farm of European seabass (Dicentrarchus labrax). Aquat Living Resour 11:247-254

KLevitt GJ, Anderson RJ, Boothroyd CJT, Kemp FA (2002) The effects of kelp harvesting on its regrowth and the understory benthic community structure at Danger Point, South Africa, and a new method of harvesting kelp fronds. S Afr J Mar Sci 24:71-85

Meals DW, Dressing SA (2008) Surface water flow measurement for water quality monitoring projects. Tech Notes 3. Developed for U.S. Environmental Protection Agency by Tetra Tech, Inc., Fairfax, VA. https://www.epa.gov/ polluted-runoff-nonpoint-source-pollution/nonpointsourcemonitoring-technical-notes

Naylor MA, Kaiser H, Jones CLW (2011) Water quality in serial-use raceway and its effect on the growth of South African abalone, Haliotus midae Linnaeus, 1758. Aquacult Res 42:918-930

Neori A, Ragg NLC, Shpigel M (1998) The integrated culture of seaweed, abalone, fish and clams in modular intensive land-based systems: II. Performance and nitrogen partitioning within an abalone (Haliotis tuberculata) and macoalgae culture system. Aquacult Eng 17:215-239
Neukermans G, Ruddick K, Loisel H, Roose P (2012) Optimization and quality control of suspended particulate matter concentration using turbidity measurements. Limnol Oceanogr Methods 10:1011-1023

Newell RC, Field JG (1983) The contribution of bacteria and detritus to carbon and nitrogen flow in a benthic community. Mar Biol Lett 4:23-36

Nobre AM, Robertson-Andersson D, Neori A, Sankar K (2010) Ecological-economic assessment of aquaculture options: comparison between abalone monoculture and integrated multi-trophic aquaculture of abalone and seaweeds. Aquaculture 306:116-126

Nydahl F (1976) On the optimum conditions for the reduction of nitrate to nitrite by cadmium. Talanta 23:349-357

* Páez-Osuna F (2001) The environmental impact of shrimp aquaculture: causes, effects, and mitigating alternatives. Environ Manag 28:131-140

* Páez-Osuna F, Guerrero-Galván SR, Ruiz-Fernández AC, Espinoza-Angulo R (1997) Fluxes and mass balances of nutrients in a semi-intensive shrimp farm in north-western Mexico. Mar Pollut Bull 34:290-297

Kaimbault P, Slawyk G (1991) A semiautomatic, wet-oxidation method for the determination of particulate organic nitrogen collected on filters. Limnol Oceanogr 36: 405-408

* Robertson-Andersson D, Potgieter M, Hansen J, Bolton JJ and others (2008) Integrated seaweed cultivation on an abalone farm in South Africa. J Appl Phycol 20:579-595

Roque d'Orbcastel E, Blancheton JP, Boujard T, Aubin J, Moutounet Y, Przybyla C, Belaud A (2008) Comparison of two methods for evaluating waste of a flow through trout farm. Aquaculture 274:72-79

Sales J, Britz PJ, Viljoen J (2003) Dietary phosphorus leaching and apparent phosphorus digestibility from different inorganic phosphorus sources for South African abalone (Haliotis midae L.). Aquacult Nutr 9:169-174

Samsukal P (2004) A preliminary study of effluent water quality of land-based abalone farms in South Africa. MSc thesis, University of Tromsø

Smith MJ (2007) Seasonal variation in nutritional content of the kelp Ecklonia maxima on the west and south west coasts of South Africa, with reference to its use as abalone feed. MSc thesis, University of Cape Town

Stavn RH, Rick HJ, Falster AV (2009) Correcting the errors from variable sea salt retention and water of hydration in loss on ignition analysis: implications for studies of estuarine and coastal waters. Estuar Coast Shelf Sci 81: 575-582

Suzumura M (2008) Persulfate chemical wet oxidation method for the determination of particulate phosphorus in comparison with a high-temperature dry combustion method. Limnol Oceanogr Methods 6:619-629

* Tan B, Mai K, Liufu Z (2001) Response of juvenile abalone, Haliotis discus hannai, to dietary calcium, phosphorus and calcium/phosphorus ratio. Aquaculture 198:141-158

Teichert-Coddington DR, Martinez D, Ramirez E (2000) Partial nutrient budgets for semi-intensive shrimp farms in Honduras. Aquaculture 190:139-145

* Tovar A, Moreno C, Mánuel-Vez M, García-Vargas M (2000) Environmental implications of intensive marine aquaculture in earthen ponds. Mar Pollut Bull 40: 981-988

Troell M, Tyedmers P, Kautsky N, Rönnebäck P (2004) Aquaculture and energy use. In: Cleveland C (ed) Encyclopedia of energy, Vol 1. Elsevier, Amsterdam, p 97-108 
Troell M, Robertson-Andersson D, Anderson R, Bolton JJ, Maneveldt G, Halling C, Probyn T (2006) Abalone farming in South Africa: an overview with perspectives on kelp resources, abalone feed, potential for on-farm seaweed production and socio-economic importance. Aquaculture 257:266-281

van der Linde DW (1998) Protocol for the determination of total suspended solids in oceans and coastal zones. Tech Note 1.98.182. Joint Research Centre, Ispra

Veitch J, Penven P, Shillington F (2009) The Benguela: a laboratory for comparative modelling studies. Prog Oceanogr 83:296-302

Viadero RC Jr, Cunningham JH, Semmens KJ, Tierne AE

Editorial responsibility: Alejandro Buschmann, Puerto Montt, Chile
(2005) Effluent and production impacts of flow-through aquaculture operations in West Virginia. Aquacult Eng 33:258-270

*Wang X, Olsen LM, Reitan KI, Olsen Y (2012) Discharge of nutrient wastes from salmon farms: environmental effects, and potential for integrated multi-trophic aquaculture. Aquacult Environ Interact 2:267-283

Yearsley RD (2007) Water quality, abalone growth and the potential for integrated mariculture on a South African abalone Haliotus midae L., farm. MSc thesis, Rhodes University, Grahamstown

Zar JH (1974) Biostatistical analysis. Prentice-Hall, Englewood Cliffs, NJ

Submitted: May 30, 2016; Accepted: December 21, 2016

Proofs received from author(s): February 13, 2017 